\title{
ISLAMISASI BUDAYA DALAM TRADISI TUJUH BULANAN (MITONI) DENGAN PEMBACAAN SURAT YŪSUF DAN MARYAM PADA JAMAAH SIMA'AN AL-QUR'AN DI DESA JURUG KECAMATAN MOJOSONGO KABUPATEN BOYOLALI
}

\author{
Laili Choirul Ummah \\ STAI Al-Anwar \\ Gondanrojo Kalipang Sarang Rembang \\ lailichoir@gmail.com
}

\begin{abstract}
Acculturation is a social process arising from a particular culture which is confronted with other cultural elements, so that these elements can be accepted without losing their own cultural character. This study focuses on the interaction of the Qur'an with Javanese culture, especially on the procession of traditions that undergoes Islamization, where Al-Qur'an is involved in it. This occurs during the recitation of Surah of Yūsuf and Maryam in the seventhmonth tradition (mitoni) in Jurug village, Mojosongo District, Boyolali Regency. The research problems discussed in this study are the causes which arises the factors of the emergence of a new culture, the factors that indicate the recitation of the Surah of Yūsuf and Maryam of Jurug village people. This study uses a qualitative research method. Data collection of this study uses participatory observation, including; interviews, observation, and documentation. With this acculturation concept, the researcher sees how the Qur'an began to infiltrate the daily lives of Jurug village people, and then uses it in the implementation of mitoni tradition by reciting the Surah of Yūsuf and Maryam in the procession of it. From the available data, as well as from the concept of acculturation, the researcher comes to a conclusion that the recitation of surah of Yūsuf and Maryam in Jurug village disseminates and grows as a norm that is believed to bring goodness and blessings to the mother and the baby she is carrying.
\end{abstract}

Keywords: Acculturation, culture, Islamization, mitoni, recitation of Surah of Yūsuf and Maryam

\begin{abstract}
Abstrak
Akulturasi adalah proses sosial yang timbul dari suatu kebudayaan tertentu, kemudian dihadapkan dengan unsur-unsur budaya lain, sehingga unsur-unsur tersebut dapat diterima tanpa menghilangkan kepribadian budaya sendiri. Penelitian ini difokuskan pada interaksi al-Qur`an dengan budaya Jawa, terutama pada prosesi tradisi yang mengalami Islamisasi, yakni tradisi mitoni di Desa Jurug, Kecamatan Mojosongo, Kabupaten Boyolali, Jawa Tengah, di mana al-Qur’an dilibatkan di dalam ritual pelaksanaannya dalam bentuk pembacaan surah Yusuf dan Maryam. Dengan konsep akulturasi ini, akan dilihat bagaimana al-Qur`an masuk dan berinteraksi secara langsung di kehidupan sehari-hari masyarakat Desa Jurug. Konteks masyarakat Desa Jurung adalah masyarakat terbuka dan ramah akan ragam tradisi termasuk mitoni, sebuah tradisi yang dilestarikan secara turun temurun dengan maksud
\end{abstract}


mendoakan janin yang dikandung ketika sudah berusia tujuh bulan. Bagi masyarakat Desa Jurung, pembacaan surah Yusuf dan Maryam pada tradisi mitoni diyakini sebagai penyambung doa yang akan mendatangkan kebaikan dan keberkahan bagi calon ibu dan bayi yang dikandungnya.

Kata kunci: Akulturasi Budaya, Islamisasi, Mitoni, Pembacaan Surat Yusuf dan Maryam

\section{A. Pendahuluan}

Al-Qur`an diturunkan bukan tanpa nilai kebudayaan, melainkan sarat dengan nilai kebudayaan dalam masyarakat. Di dalamnya memuat tema-tema yang mencakup seluruh aspek relasi manusia dengan Tuhan, relasi sesama manusia, dan relasi manusia dengan alam sekitarnya.1Al-Qur`an datang dengan sarat nilai di dalamnya, dan Indonesia berkembang dengan tradisi-tradisi yang melingkupinya, sehingga benturan antar keduanya dinilai tidak akan didapati titik temu bersama. Pribumisasi Islam (baca: al-Qur`an), usaha mengadaptasikan tradisi-tradisi lokal dengan ajaran Islam tanpa merusak esensi nilai subtansinya membuktikan bahwa antara Islam dan budaya-budaya lokal dapat berjalan secara beriringan tanpa saling menjatuhkan, sehingga tercipta harmoni bersama.

Letak geografis Negara Indonesia yang strategis, sangat menguntungkan bagi bangsa Indonesia, karena letaknya bisa dijadikan lalu lintas perdagangan dunia.Sehingga sangat memungkinkan bagi bangsa Indonesia untuk berinteraksi dengan bangsa-bangsa besar dunia tersebut, termasuk wiraniagawan bangsa $\mathrm{Arab}^{2}$ yang kemudian secara berlahan mengubah alur sejarah teologi bangsa Indonesia.Beragam teori dicetuskan untuk menjawab kapan tepatnya bangsa Arab mulai memasuki wilayah Indonesia dengan membawa misi Islam.

Ibrahim Buchari dalam risetnya pada sebuah nisan Syaikh Mukaiddin yang terletak di Baros, Tapanuli yang tertulis penanggalan tahun 48 Hijriyah atau 670 Masehi berkesimpulan bahwa Islam masuk di Indonesiapada abad ke-7 Masehi. ${ }^{3}$ Teori ini selaras dengan sebuah tulisan dalam catatan berita Cina, Dinasti Tang, yang menuturkan bahwa ditemuinya daerah hunian wirausahawan Arab Islam di pantai barat Sumatra pada tahun $674 \mathrm{M}^{4}$ Dari data tersebut asumsi kuat bahwa Islam masuk di Indonesia sejak abad 1 Hijriyah. Teori tersebut juga dikuatkan oleh exterbal source, dalam kitab Nukhbat al-Dahr fi 'Ajāib al-Barr wa al-

\footnotetext{
${ }^{1}$ M. Quraish Shihab, dkk, Sejarah dan Ulum al-Qur`an (Jakarta: Pustaka Firdaus, 2001), hlm. 1.

${ }^{2}$ Faizah Amin \& Rifki Abror Ananda "Kedatangan dan Penyebarana Islam di Asia Tenggara: Tela'ah Teoritik Tentang Proses Islamisasi Nusantara” , Analisis: Jurnal Studi Keislaman, vol. 18, no. 2 (2018), hlm.74.

${ }^{3}$ Ahmad Mansur Surya Negara, Api Sejarah Jilid I (Bandung: Surya Dinasti: 2016), hlm.108.

${ }^{4}$ Ibid., hlm. 108.
} 
Islamisasi Budaya dalam Tradisi Tujuh Bulanan .....

Laili Choirul Ummah

Doi: doi.org/10.47454/itqan.v4i2.686

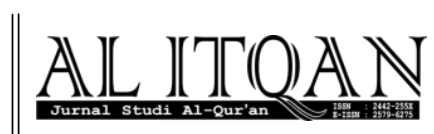

Baḥr yang ditulis oleh Syaikh al-Rabwah5.al-Rabwah menyatakan bahwa wirausahawan Indonesia telah melakukan kontak perdagangan dengan bangsa Arab pada masa Khalifah Uthmān bin 'Affān (24-36 H./644-656M.). Kontak tersebut dimulai saat niagawan muslim Arab melakukan kunjungan niaga ke Cina. Kesempatan inilah yang kemudian dimanfaatkan untuk mengadakan kontak dagang dengan wirausahawan di Indonesia. Demikian pula dengan J.C Van Leur dalam Indonesian Trade and Society, ia menulis pernyataan yang sama dengan catatan berita Cina, Dinasti Tang. Sehingga, Islam menjadi agama mayoritas rakyat Indonesia, dulu hingga sekarang berkat usaha para pendakwah dan ulama tanpa adanya tindak kekerasan pada penyebarannya.

Islam berkembang di Indonesia adalah hasil perbincangannya dengan budaya setempat.Pada masa pra-Islam masyarakat Indonesia telah menganut kepercayaan dan mempunyai budaya yang beragam. Islam masuk di Indonesia, khususnya di Jawa dengan cara damai sehingga mudah menyesuaikan diri dengan keadaan masyarakat Jawa guna menyeimbangan antara nilai tradisional Jawa dan nilai agama Islam. Penyebaran ajaran Islam di Jawa didominasi oleh bentuk akulturasi, dimana kekuasaan politik kerajaan Islam Jawa yang mempertemukan Islam Jawa dengan kosmologi Hinduisme dan Budhisme. ${ }^{6}$ Dari sini tergambar wajah Islam Jawa yang akulturatif terlihat lebih dominan.

Proses interaksi dan adaptasi al-Qur`an dengan budaya Indonesia memberikan label alQur`an pada keyakinan diri individunya bahwa al-Qur`anmberkahi, al-Qur`an sebagai penyambung doa, al-Qur`an sebagai penyembuh penyakit, dan lainnya.

Islamisasi, interaksi, adaptasi al-Qur`an dengan budaya diwujudkan dengan keterlibatan al-Qur`an pada prosesi ritual tradisi jawa. Salah satunya pada pembacaan Surat Yūsuf dan Maryam dalam tradisi tujuh bulanan (mitoni) pada majelis Sima'an al-Qur’an di Desa Jurug, Kecamatan Mojosongo, Kabupaten Boyolali, Jawa Tengah.

Pada sejarahnya, tradisi motoni didominasi dengan ritual-ritual jawa, seperti siraman, proses menyiram atau mengguyurkan air pada diri ibu hamil sebanyak tujuh kali yang dilakukan oleh orang yang berbeda-beda. Setelah siraman, ibu yang mengandung memakai jarik sebanyak tujuh kali secara bergantian.Kemudian diadakan kenduren (tasyakuran) yang di

\footnotetext{
${ }^{5}$ Memiliki nama asli

${ }^{6}$ Ummi Sumbulah, “Islam jawa dan Akulturasi Budaya: Karakteristik, Variasi, dan Ketaatan Ekspresif” , el Harakah,vol.14, no.1(2012),hlm. 51.
} 
rumah shahibul hajat pada sore hari, dan pada malam harinya diadakan lek-lekan (begadang) yang dihadiri oleh warga sekitar. ${ }^{7}$

Tradisi ini juga dipelihara oleh masyarakat Jawa secara luas dengan proses ritual yang bereda, seperti mengadakan pertunjukan wayang kulit semalam suntuk dengan cerita lakon tentang kelahiran seorang Pandawa atau tokoh keramat dalam dunia pewayangan. ${ }^{8}$ Dengan harapan bayi yang dikandung kelak ketika lahir menjadi sosok yang berguna bagi keluarganya, masyarakatnya, dan kehidupannya.

Masyarakat Desa Jurug masih melestarikan tradisi-tradisi Jawa, seperti sewengenan, lapanan, rewang dan lainnya, namun dalam pelaksanaannya telah mengalami penyisipan ajaran-ajaran Islam, termasuk dalam pelaksanaan tradisi mitoni. Hipotesis tulisan ini menyatakan bahwa, tradisi mitoni yang dilakukan oleh masyarakat Desa Jurug, khususnya pada Majelis Sima'an al-Qur`an telah mengalami Islamisasi, yaitu dengan adanya pembacaan Surat Yūsuf dan Maryam dalam rangkaian ritualnya. Hal ini dipengaruhi oleh adanya pengajian yang disampaikan oleh tokoh agama setempat, yang menjelaskan bahwa kandungan Surat Yūsuf dan Maryam bila dibacakan pada tradisi tujuh bulanan (mitoni) akan mendapatkan keberkahan dalam hidupnya dan dalam bentuk rupa maupun perilaku yang baik, seperti Nabi Yūsuf yang rupawan dan kesalehahan Siti Maryam, selain itu pembacaan surat ini juga sebagai wujud doa mengharap ketularan diberi rizki kehamilan. ${ }^{9}$

Penelitian ini fokus pada pelaksanaan tradisi mitoni yang dilakukan oleh masyarakat Desa Jurug, Kecamatan Mojosongo, Kabupaten Boyolali, Jawa Tengah. Bagaimana sejarah tradisi mitoni, ritual-ritual yang dilakukan, faktor-faktor yang melatarbelakangi lahirnya tradisi mitoni, serta untuk mengetahui hubungan antara penggunaan al-Qur`an dan kebudayaan Jawa.

\section{B. KerangkaTeori}

Model kajian living Qur`an adalah model kajian yang menjadikan fenomena yang hidup di tengah masyarakat muslim, terkait dengan al-Qur`an dan masyarakat sebagai objek

\footnotetext{
${ }^{7}$ Wawancara dengan Suyati, Boyolali, 13 Oktober 2018.

${ }^{8}$ Koentjaraningrat, Kebudayaan Jawa (Jakarta: Balai Pustaka, 1994), hlm. 350.

${ }^{9}$ Suyati, Wawancara, Boyolali, 13 Oktober 2018.
} 
Islamisasi Budaya dalam Tradisi Tujuh Bulanan .....

Laili Choirul Ummah

Doi: doi.org/10.47454/itqan.v4i2.686

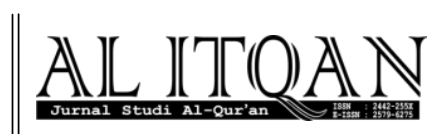

kajiannya. ${ }^{10}$ Kajian tentang al-Qur`an yang bertumpu fenomena kebudayaan yang lahir atas kehadiran al-Qur`an di tengah masyarakat tertentu.

Teori yang digunakan untuk menganalisi interaksi masyarakat dengan al-Qur`an dalam bentuk pembacaan surat Yusuf dan Maryam dalam tradisi mitoni adalah teori Farid Esack dan Roobert E Van Voorst. Esack dalam bukunya The Qur`an: AShortIntroduction, Farid esack mengklasifikasikan hubungan teks al-Qur`an menjadi tiga kategori. Pertama, pecinta tidak kritis (the uncriticallover), mereka selalu menyanjung, memuji dan memuja alQur`an. Bagi mereka al-Qur`an adalah obat segala penyakit, solusi bagi setiap masalah, dan jawaban atas segala persoalan, meskipun mereka sendiri tidak tahu bagaimana untuk memperoleh suatu jawaban tersebut. Kedua,pecinta ilmiah (the scholarly lover), kategori ini dihuni oleh mereka yang terpesona dengan keindahan al-Qur`an, dengan tidak menjadikan mereka lupa untuk mengkaji lebih dalam tentang aspek keindahan atau mukjizat al-Qur`an tersebut dari sisi ilmiahnya. Kemampuan intelektual dan kecerdasan yang mereka miliki digunakan untuk mengkaji al-Qur`an secara ilmiah dari beragam aspek dalam al-Qur`an seperti i'jāz al-Qur`an keindahan al-Qur`an, aspek bahasa dan susunan redaksi kalimatnya, sejarahnya, hingga isyarat-isyarat ilmiah yang terkandung didalamnya. Hasil dari kajian tersebut kemudian mereka tuangkan dalam karya-karya ilmiah, seperti kitab tafsir serta bukubuku ilmiah yang mengkaji al-Qur`an.

Ketiga, pecinta kritis (the critical lover) kategori ini digandrungi mereka yang memposisikan al-Qur`an tidak hanya sekedar sebagai kekasih yang sempurna dan tanpa cela, tetapi ia menjadikannya sebagai objek kajian menarik yang perlu dilakukan. Demi mengetahui banyak hal yang ada dalam al-Qur`an, sang pecinta mau menggunakan perangkat ilmiah modern seperti hermeneutika, linguistik, antropologi, sosiologi, psikologi, bahkan filsafat sebagai pisau analisanya. Melalui metode ini, para pecinta bisa mengkaji lebih dalam makna yang tersirat dalam al-Qur`an. Hasil kajian ini kemudian dituangkan dalam bentuk karya ilmiah yang fresh from the oven. Sebuah hasil studi pemikiran yang segar dan mampu berdialektika, bahkan mampu menjawab tantangan dan problematika zaman.

Tiga kategori tersebut dibangun Esack dengan menggunakan analogi hubungan pecinta dantubuh seorang kekasih (the lover and body of abeloved). Pecinta dan tubuh

10 M. Mansur, “Living Qur`an dalam Lintasan Sejarah Studi Qur`an, dalam Sahiron Syamsuddin (ed.), Metodologi Penelitian Living Qur`an dan Hadis (Yogyakarta: TH Press, 2007), hlm. 7. 
seorang kekasih, masing-masing tersebut diwakili dengan pembaca teks al-Qur`an dan teks alQur`an. $^{11}$

Sementara Roobert E Van Voorst membagi fungsi kitab suci dalam masyarakat menjadi tiga bentuk. Pertama kognitif, penggunaan ini mencakup bahwa kitab suci menjadi sumber membangun dan mempertahankan doktrin-doktrin atau ajaran-ajaran, kebenarankebenaran tentang semesta, dan cara yang benar untuk hidup di dalamnya. ${ }^{12}$ Van Vorst menjelaskan;

Scripture is a source for establishing and defending key doctrines. Scriptures can be used doctrinally because they typically contain the key teachings of the faith and because believers usually see them as continuing the voice of the founders. They have primary importance as statements of the deep truths of the universe and the right way to live in it. These teachings can assume different forms: $\operatorname{God}(\mathrm{s})$ and humanity; human imperfections and salvation; beginnings and ends of the individual and the cosmos; the moral life and how to achieve it. $^{13}$

Tulisan suci adalah sumber untuk menegakkan dan mempertahankan ajaranajaran kunci. Kitab Suci dapat digunakan secara doktrin karena berisi ajaranajaran kunci iman dan karena orang percaya biasanya melihatnya sebagai melanjutkan suara para pendiri. Mereka memiliki kepentingan utama sebagai pernyataan tentang kebenaran mendalam tentang alam semesta dan cara yang benar untuk hidup di dalamnya. Ajaran-ajaran ini dapat mengambil bentuk yang berbeda: Tuhan dan kemanusiaan; ketidaksempurnaan dan keselamatan manusia; awal dan akhir individu dan kosmos; kehidupan moral dan bagaimana (cara) mencapainya.

Kedua non-kognitif, penggunaan yang tidak memiliki hubungan dengan pengembangan pengetahuan. ${ }^{14}$ Selain itu, penggunaan non-kognitif ini ditekankan pada aspek spiritual, yang mana kitab suci dipercaya mendatangkan keberkahan dan menjauhkan dari kejahatan. Penggunaan non-kognitif ini akan membangun kepercayaan dan keyakinan pada individu mayarakat terhadap al-Qur`an, al-Qur`an memiliki kekuatan, memberi berkah, menyembuhkan, menolak kejahatan, dan lainnya sehingga menggunakannya sebagai jimat dan matra. Sebagaimana yang dikatakan oleh Van Vorst, bahwa;

Noncognitive application stresses the objective spiritual power of a holy book. The power of scripture is such that it can bring blessing and keep away evil. Scripture can be used in charms or talismans, a manifestation of the

\footnotetext{
${ }^{11}$ Faridesack, The Qur`an: A Short Introduction (London:One world Publication, 2002), hlm. 2.

${ }^{12}$ Robert E. Van Vorst, Anthilogy of World Scriptures (USA: Thomson Corporation, 2008), hlm. 8.

${ }^{13}$ Ibid., hlm. 8.

${ }^{14}$ Ibid., hlm. 10.
} 

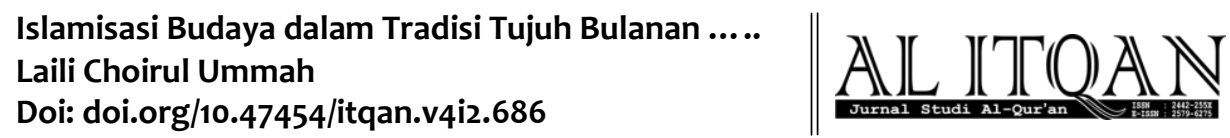

supernatural power of scripture. The mere possession of a holy book also has power to bless and to ward off evil. ${ }^{15}$

Penerapan nonkognitif menekankan kekuatan spiritual obyektif dari sebuah kitab suci. Kuasa tulisan suci sedemikian rupa sehingga dapat mendatangkan berkat dan menjauhkan kejahatan. Kitab Suci dapat digunakan dalam jimat atau jimat, sebuah manifestasi dari kekuatan supernatural kitab suci. Memiliki sebuah kitab suci juga memiliki kekuatan untuk memberkati dan menangkal kejahatan.

Ketiga, kitab suci juga dikaji dari segi informatif dan segi peformatif. Dari aspek informatif, al-Qur`an dijadikan sebagai sumber pengetahuan, doktrin, sejarah masa lalu, isyarat ilmu pengetahuan, dan sebagainya. Selain itu, dalam konteks performatif, al-Qur`an berfungsi sebagai sesuatu yang ditampilkan, seperti dilagukan dan dilombakan dalam konteks keislaman. $^{16}$

\section{MetodePenelitian}

Jenis penelitian ini adalah kualitatif. Sebuah prosedur penelitian yang menghasilkan data deskriptif berupa kata-kata tertulis atau lisan dari orang-orang terlibat dan perilaku yang diamati. ${ }^{17}$ Penelitian ini bermaksud untuk memahami fenomena terhadap sesuatu yang dialami oleh subjek penelitian, seperti; motivasi masyarakat terhadap pembacaan Surat Yūsuf dan Maryam dalam tradisi tujuh bulanan (mitoni).

Penelitian ini mengacu pada dua sumber data, yaitu data primer dan sekunder. Data primer yang digunakan adalah catatan pengajian dalam tradisi tujuh bulanan (mitoni).Data ini bisa berupa; wawancara, observasi, dokumentasi, pengamatan pengajian, rekaman, maupun catatan-catatan yang diperoleh saat penelitian dilakukan. Data sekunder yang digunakan dalam penelitian ini adalah buku atau jurnal, kepustakaan yang berhubungan dengan objek formal. Data ini bisa berupa; arsipdesa dan beberapa data yang berhubungan dengan tujuh bulanan (mitoni).

Penelitian ini dilaksanakan di Desa Jurug, Kecamatan Mojosongo, Kabupaten Boyolali, Jawa Tengah. Desa Jurug memiliki luas 241,304 hektare dan terdiri dari empat Dusun, yaitu Dusun Slembi, Semaran, Marteng, dan Jurug. ${ }^{18}$ Desa ini signifikan untuk dikaji, karena di satu sisi masyarakat setempat masih melaksanakan tradisi-tradisi Jawa yang

\footnotetext{
${ }^{15}$ Ibid, hlm. 9 .

${ }^{16}$ Ibid, hlm. 10.

${ }^{17}$ Lexy j. Moleong, Metode Penelitian Kualitatif (Bandung:Rosda Karya, 2004), hlm. 3.

${ }^{18}$ Monografi Desa Jurug Kecamatan Mojosongo Kabupaten Boyolali Tahun 2018. Tanggal 29 Oktober 2018.
} 
dianggap sakral dan terjaga,yaitu dengan memberi sesajen pada tempat-tempat yang dianggap keramat oleh masyarakat, seperti; sumur sungai, makam, pohon besar, batu besar, dan pojokan Desa. Tradisi lain yang masih terjaga dan rutin dilakukan adalah tradisi siklus kehidupan seperti kelahiran (mitoni, sewengenan, aqiqahdan lapanan), kematian (layat, pendak pisan,pendakpindo, nyewu), perikahan (rewang), dan lainnya.

Kedatangan Islam membawa perubahan dalam pelaksanaa tradisi-tradisi tersebut, seperti pada tradisi tujuh bulanan (mitoni) yang sebelumnya sangat kental dengan ritual-ritual jawa seperti siraman, kenduren, lek-lekan, kemudian dimodifikasi dengan ajaran-ajaran Islam dengan memberikan sedekah kepada tetangga terdekat dan juga mengadakan sima'an alQur`an dengan pembacaan Surat Yūsuf dan Maryam.

Data objek penelitian ini diperoleh dari pelaku-pelaku tradisi mitoni yakni Ibu Nyai Siti Mukarromah dan Bapak Kiai Khoirun selaku pendiri majelis sima'an al-Qur'an Idkhōl alSurūr, Suyati, Sri Rahayu, Sri Yamini, dan Abu Hamid, serta masyarakat lainnya.

Dalam kegiatan observasi partisipatif, seorang peneliti harus melihat dan mendengarkan apa saja yang dilakukan dan dikatakan oleh para responden dalam aktivitas kehidupan sehari-hari baik sebelum, menjelang, ketika, dan sesudah tradisi berlangsung. Aktivitas yang diamati, yaitu yang berkaitan dengan topik penelitian. Kegiatan ini harus dilakukan dengan tanpa seorang responden merasa sedang diamati. Karena teknik ini diperlukan untuk menghilangkan kecurigaan para responden terhadap peneliti. ${ }^{19}$

Dalam penelitian ini, data diambil dari hasil wawancara dan dokumentasi terhadap masyarakat Desa Jurug terkait pembacaan Surat Yūsuf dan Maryam dalam tradisi tujuh bulanan (mitoni). Agar data dapat memberikan makna dalam analisa yang dilakukan, maka data mengalami reduksi, yaitu proses pesekelsi data terkait hasil wawancara bersama masyarakat dan memfokuskan data pada permasalahan yang dikaji, dengan demikian, data hasil reduksi akan memberikan gambaran yang jelas.

Pada tahap selanjutnya, data-data hasil reduksi akan dianalisis menggunakan teori Farid Esack dan Van Vorst,. Tahap terakhir adalah verivikasi, data yang dimaksudkan untuk menentukan kesimpulan dari keseluruhan proses tahapan analisa. Sehingga seluruh

\footnotetext{
${ }^{19}$ Abdul Mustaqim, Metode Penelitian Living Qur`an Model Penelitian Kualitatif (Yogyakarta: Teras, 2007), hlm. 74 .
}

\section{AL-ITQAN, Volume 4, №. 2, 2018}




\section{Islamisasi Budaya dalam Tradisi Tujuh Bulanan ..... \\ Laili Choirul Ummah \\ Doi: doi.org/10.47454/itqan.v4i2.686}

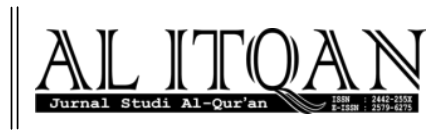

permasalahan tentang pembacaan Surat Yūsuf dan Maryam pada tradisi tujuh bulanan (mitoni) oleh masyarakat Desa Jurug dapat dijawab sesuai dengan data yang diperoleh.

\section{Tradisi Mitoni}

Berinteraksi dengan al-Qur`an merupakan salah satu pengalaman beragama yang berharga bagi seorang Muslim. Pengalaman berinteraksi dengan al-Qur`an dapat diungkapkan melalui tulisan, lisan, maupun perbuatan, baik berupa pemikiran, pengalaman emosional maupun spiritual dan pengalaman tersebut dapat menghasilkan pemahaman dan penghayatan terhadap ayat-ayat al-Qur`an tertentu. Sehingga, setiap Muslim berkeyakinan bahwa alQur`an adalah wahyu dari Allah yang diturunkan kepada umat manusia sebagai petunjuk dan pedoman hidup. $^{20}$

Dari hasil observasi, fenomena interaksi jamaah simaan al-Qur`an dan pembelajaran jamaah terhadap al-Qur`an menyatakan bahwa beberapa kegiatan tersebut mencerminkan living Qur`an, kehadiran al-Qur`an di tengah kehidupan masyarakat, seperti pembacaan Surat Yūsuf dan Maryam dalam tradisi tujuh bulanan (mitoni).

\section{Pembacaan Surat Yūsuf dan Maryam dalam Tradisi Mitoni}

Tradisi mitoni ini biasanya sudah dipersiapkan oleh siempunya hajat, seperti kapan dan dimana acara akan dilaksanakan. ${ }^{21}$ Tuan rumah menyiapkan botol yang berisi air mineral untuk mendapat barokah dari pembacaan Surat Yūsuf dan Maryam tersebut, yang kemudian airnya diminum oleh si calon ibu, dengan harapan bayi yang dikandung diberi keselamatan dan keberkahan. ${ }^{22}$ Hal tersebut mencerminkan bahwa masyarakat mempercayai kitab suci;

Dengan demikian, teori non-kognitif Roobert E Van Voorst diaplikasian oleh masyarakat Desa Jurug dalam meyakini bahwa air mineral yang dibacakan Surat-surat dalam al-Qur`an akan memberikan keberkahan. Sehingga, dengan meminum air tersebut, maka akan mendapatkan keberkahan pula.

Jamaah sima'an al-Qur`an ini didominasi oleh ibu-ibu, dikarenakan pimpinan majelis ini adalah seorang Ibu Nyai. Setelah semua jamaah berkumpul dan Ibu Nyai telah datang, maka dimulailah pembacaan al-Qur`an, dengan para jamaah menyimak hafalan Ibu Nyai Siti

\footnotetext{
${ }^{20}$ Muhammad Chirzin, Mengungkap Pengalaman Muslim Berinteraksi dengan al-Qur`an (Yogyakarta: Teras, 2007), hlm. 12.

${ }^{21}$ Wawancara dengan Suyati, 13 Oktober 2018.

${ }^{22}$ Ibu Suyati dan Sri Widyastuti (calon ibu yang mengandung), observasi, pada 12 Oktober 2018.
} 
Mukarromah yang membaca Surat Yūsuf dan Maryam Air yang telah disiapkan dibuka supaya mendapat keberkahan dari ayat al-Qur`an yang dibaca. ${ }^{23}$

Kitab suci dalam majelis sima'an al-Qur`an digunakan sebagai aspek kognitif. ${ }^{24}$ Diketahui bahwa dari pembacaan al-Qur`an yang dilakukan oleh Ibu Nyai Siti Mukarromah sebagai simbol memperingati tradisi tujuh bulanan (mitoni).

Dalam prosesi ini dapat disimpulkan bahwa al-Qur`an digunakan sebagai aspek nonkognitif. Karena al-Qur`an menjadi simbol yang dibacakan dan dipercayai akan mendatangkan berkah dalam tradisi mitoni. Sehingga, di dalamnya mengandung unsur sugesti untuk dilakukan dalam tradisi mitoni, meskipun masyarakat tidak mengetahui secara rinci makna yang terkandung, informasi, atau pengetahuan mendalam yang terdapat dalam Surat Yūsuf dan Maryam.

\section{Prosesi Kenduren dalam Tradisi Mitoni}

Setelah majelis sima'an al-Qur’an selesai dan semua jamaah telah meninggalkan rumah yang mempunyai hajat, maka ritual selanjutnya adalah kenduren. Kenduren merupakan suatu tradisi yang muncul di tengah masyarakat yang dilaksanakan pada momen-momen tertentu. Seperti pendapat Ahmad Kholil, bahwa tradisi kenduri dilaksanakan dalam berbagai kegiatan yang dianggap perlu penghormatan khusus, seperti hal-hal yang berhubungan dengan kelahiran, pernikahan,bahkankematian. ${ }^{25}$

Tradisi kenduren mitoni di Desa Jurug ini dilaksanakan guna melestarikan budaya Jawa yang masih melekat dalam kehidupan masyarakat. Hal-hal yang perlu disiapkan dalam tradisi ini adalah segala bentuk makanan yang berupa dan berjumlah tujuh. sebagai simbol kehamilan yang telah memasuki bulan ke-tujuh. Seperti yang dikatakan oleh Koentjaraningrat, bahwa hidangan untuk acara slametan mitoni ini terdiri dari tujuh buah nasi tumpeng dengan tujuh macam lauk pauk, dan tujuh macam jenang dengan warna yang berbeda-beda pula. Hidangan slametan yang disajikan tersebut juga harus mempunyai makna yang melambangkan kelahiran yang cepat dan selamat. Misalnya, salah satu jenang tersebut diberi nama jenangprocot, hal tersebut dimaksudkan agar kelak pada waktu melahirkan

\footnotetext{
${ }^{23}$ Ibu Suyati dan Sri Widyastuti (calon ibu yang mengandung), observasi, pada 12 Oktober 2018.

${ }^{24}$ Sam D.Gill, Nonliterate Tradition and Holy Books: Toward a New Model (t.t: Denny and Taylor Holly Book, $\mathrm{t}, \mathrm{th}), \mathrm{hlm} .234$.

25 Ahmad Kholil, "Seblang dan Kenduri Masyarakat Desa Oleh sari: Relasi Ideal Antara Islam dan Budaya Jawa di Banyuwangi"el-Harakah, vol.12, no.2 (2010), hlm. 132.
} 
Islamisasi Budaya dalam Tradisi Tujuh Bulanan .....

Laili Choirul Ummah

Doi: doi.org/10.47454/itqan.v4i2.686

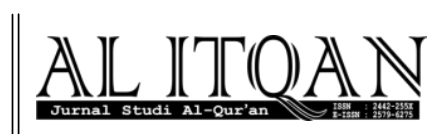

bayinya dapat dengan mudah $\left(\right.$ procot $=$ cepat keluar) ${ }^{26}$ Hal tersebut juga ditemukan pada tradisi mitoni masyarakat Desa Jurug, setelah semua hidangan tersaji, maka tuan rumah atau bapak Slamet Nuryadi (ayah menantu yang sedang hamil) mengundang warga (bapak-bapak) sekitar, khususnya yang tinggal di RT 01/RW 06 Desa Jurug untuk menghadiri acara kenduren di rumah bapak Slamet Nuryadi pada pukul 17.00.

Warga yang hadir duduk melingkar dengan hidangan kenduren didalamnya. Setelah semua warga undangan hadir, maka acara segera dimulai.Untuk acara kenduren ini terbilang singkat, namun padat makna. Acara di buka oleh tokoh masyarakat, dimulai dengan pembacaan Surat Al-Fātiḥah kemudian dilanjutkan dengan doa-doa. Doa tersebut dipintakan dan diharapkan untuk keselamatan calon ibu dan bayi yang dikandungnya dan juga agar mendapatkan keberkahan hidupnya.

\section{Akulturasi Budaya}

Kehadiran Islam di Indonesia oleh para pendakwah yang memiliki fungsi ganda, yaitu karena disamping membawa misi Islam, mereka juga berfungsi sebagai saudagar. Sebagaimana perkataan Robson yang dikutip Woodward, mereka para saudagar medirikan komunitas-komunitas kemudian menggandeng para sufi, ulama yang ditugaskan dan dipertanggung jawabi untuk menegarkan Islam di tanah Jawa. ${ }^{27}$ Metode dakwah yang digunakan adalah secara persuasif dan adaptif dengan tradisi atau budaya Indonesia. Sehingga terjadi asimilasi dan akulturasi timbal balik antara Islam dengan budaya masyarakat setempat. Penyebaran Islam secara damai dengan tradisi dan budaya masyarakat setempat memberi pengaruh terhadap percepatan proses Islamisasi di Indonesia.

Menurut a ahli sejarah, penyebaran Islam secara damai dan adaptatif di tanah Jawa dipengaruhi tiga hal: pertama, para penyebar Islam yang datang ke Indonesia dari kalangan ulama, pedagang, dan para ahli tasawuf. Para pedagang tersebut melakukan perdagangan secara baik-baik, menetap, hingga tinggal dan menjadi penduduk Jawa, sedangkan para sufi mengajarkan Islam dengan menekankan pada olah jiwa atau kebatinan. Kedua, sifat orang Jawa yang ramah, sehingga dapat dengan mudah menerima sesuatu yang datang dari luar, lalu diselaraskan dengan prinsip dan budayanya sendiri. Dengan begitu, banyak ajaran mistik Islam yang justru lebih mudah dipahami oleh orang Jawa. Ketiga, melalui jalan perkawinan,

\footnotetext{
${ }^{26}$ Koentjaraningrat, Kebudayaan Jawa (Jakarta: Balai Pustaka, 1994), hlm. 350.

${ }^{27}$ Mark R. Woodward, Islam Jawa; Kesalehan Normatif Versus Kebatinan, terj. Hairus Salim HS(Yogyakarta: LkiS, 2012), hlm. 84.
} 
para pendakwah dengan giat mengajarkan agama Islam (dalam proses sosial pendatang menikah dengan priibumi), maka dengan itu mereka dapat dengan mudah untuk mendapatkan pengikut. $^{28}$ Dengan begitu, ketika Islam dan budaya lokal menyatu, maka akan tercipta budaya-budaya baru, akulturasi, yang mempengaruhi interaksi dan pemahaman masyarakat pada al-Qur`an.

Akulturasi menurut kamus besar Bahasa Indonesia adalah percampuran dua kebudayaan atau lebih yang saling bertemu dan saling mempengaruhi. ${ }^{29}$ Proses akulturasi merupakan dampak dari kenyataan bahwa setiap kebudayaan selalu mengalami persebaran, yang mana ketika manusia muncul, maka saat itu juga muncul suatu kebudayaan. Dengan demikian, kebudayaan asal tersebut berkembang, menyebar dalam berbagai kebudayaan baru karena terjadinya perubahan waktu dan tempat. Kemudian, manusia semakin lama juga semakin berkembang, menyebar menjadi suku-suku dan bangsa-bangsa, sehingga berpengaruh pada pernyebaran budaya mereka.

Kitabsuciyang hadir dalam kehidupanmasyarakatdan dikontruksikan dalam bentuk suatu kegiatanmerupakanbagiandari hasil interaksi al-Qur`an dengan budaya.Budaya sebagai akab budi, pikirann, adat istiadat, ${ }^{30}$ sedangkan Islamadalah agama yang diajarkan Nabi Muhammad dengan berpedoman pada wahyu Allah berupa al-Qur`an, yang padat akan nilainilai ketuhanan. ${ }^{31}$ Sehingga kebudayaan Islam adalahasilakal,budi,cipta rasa dankaryamanusia yang berdasarkan pada nilai-nilai Ketuhanan. Dengan begitu, kajian ini bisa dikatakan dengan penyatuan budaya lokal dengan budaya Islam dalam wujud pelestarian lokal tujuh bulanan (mitoni) dengan memasukkan pembacaan al-Qur`an, yaitu Surat Yūsuf dan Maryam dalam pelaksanaan ritualnya. Akulturasi Islam dengan budaya lokal adalah sebuah proses terjadinya pertemuan atau hubungan timbal balik antara Islam dengan budaya masyarakat setempat, sebagaimana yang terjadi dalam kehidupan jamaah sima'an al-Qur`an Desa Jurug, Kecamatan Mojosongo, Kabupaten Boyolali, Jawa Tengah.

Al-Qur`an diyakini sebagai kitab suci umat Islam yang memuat banyak hal dan bisa digunakan untuk banyak hal, seperti al-Qur`an yang memuat kisah Nabi Zakariyya yang memohon diberikan keturunan ${ }^{32}$. Pada kemudian hari surah yang memuat kisah ini digunakan

\footnotetext{
${ }^{28}$ M.Hariwijaya,IslamKejawen(Yogyakarta:GelombangPasang,2006),hlm. 196.

${ }^{29}$ Pusat Bahasa, Kamus Bahasa Indonesia (Jakarta: departeman Pendidikan Nasional, 2008), hlm. 33

${ }^{30}$ Ibid., hlm. 226.

${ }^{31}$ Harun Nasution, Ensiklopedi Islam Indonesial (Jakarta: Djambatan, 1992), hlm. 849.

${ }^{32}$ Lihat QS. Maryam: 3-6.
} 
Islamisasi Budaya dalam Tradisi Tujuh Bulanan .....

Laili Choirul Ummah

Doi: doi.org/10.47454/itqan.v4i2.686

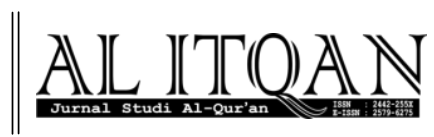

sebagai tawasul permohonan doa supaya diberi diberi keturunan yang salih salihah oleh masyarakat muslim. Farid Esack menyatakan bahwa Al-Qur'an fulfills many of fuction in lives of Muslims ${ }^{33}$ Al-Qur'an mampu memenuhi banyak fungsi di dalam kehidupan umat Islam. Hal ini terjadi pada jamaah sima'an al-Qur`an Desa Jurug, yang mana al-Qur`an difungsikan sebagai pembawa keberkahan, kebaikan, dan keselamatan dalam prosesi tujuh bulanan (mitoni) dengan pembacaan Surat Yūsuf dan Maryam. Dengan demikian al-Qur`an adalah kitab yang șahịh likulli zamān wa makān, yang selalu dibaca, dikaji, dipelajari, dan dikembangkan sejak diturunkan hingga sekarang.

Sistem dan metode yang ditempuh oleh para pendakwah Islam dalam menyiarkan Islam ke seluruh penjuru dunia adalah sama seperti yang dilakukan oleh Nabi Muhammad Salla Allahu Alayhi wa Sallam dan para sahabatnya, ketika berdakwah menyebarkan ajaran Islam kepada bangsa Arab. Arab dan Islam yang bergumul sedemikian rupa di kawasan Timur Tengah menjadikan orang kesulitan membedakan antara nilai Islam dan simbol budaya bangsa Arab. Kemudian Nabi Muhammad Salla Allahu Alayhi wa Sallam dengan petunjuk Allah Subnahahu wa Ta'ala segera mengetahui keadaan sosiologi masyarakat Arab pada saat itu, sehingga Nabi menggunakan tradisi Arab untuk mengembangkan Islam. Sebagai salah satu contoh bahwa Jubah adalah pakaian bangsa Arab secara umum. Namun, dengan adanya Islam masuk di jazirah Arab, Nabi pun tidak mengubah dan membedakan cara berpakaian orang Islam dengan orang jahiliah. Dengan demikian, Islam tidak memindahkan simbol budaya yang ada di Timur Tengah sebagai tempat lahirnya agama Islam. Sebagaimana gagasan Kuntowijoyo tentang budaya Islam memiliki dua karakter. Pertama; Otentik, berarti bahwa budaya Islam dalam keadaan bagaimana pun dan kapan pun akan selalu berfungsi untuk menampilkan nilai-nilai kehidupan. Kedua; terbuka, berarti bahwa Islam tetap mengadopsi budaya setempat, selama tidak bertentangan dengan al-Qur`an dan Hadith. ${ }^{34}$

Kehadiran Wali Songo sebagai pendakwah Islam awal di Jawa juga memberi andil besar dalam berbagai bidang kehidupan pada masyarakat jawa, terutama dibidang kebudayaan. Para pendakwah Islam awal berupaya mengakulturasikan istilah-istilah HinduBudha kedalam istilah-istilah Islam di berbagai bidang kegiatanseperti pendidikan, pengajaran, kesenian, hiburan dan sebagainya. Dalam media tersebut telah digunakan secara kreatif dan maksimal oleh para pendakwah untuk dijadikan tali penghubung untuk

\footnotetext{
${ }^{33}$ Farid Esack, The Qur`an: A Short Introduction (England: One world Publication, 2002), hlm. 16.

${ }^{34}$ Kuntowijoyo, Dinamika Sejarah Umat Islam di Indonesia (Yogyakarta: Mata Bangsa, 2017), hlm 43.
} 
mengislamkan tanah Jawa yang masih sangat kental dengan tradisi Hindu-Budha dan tradisi Animisme-Dinamisme. Strategi yang diterapkan oleh para pendakwah secara popular menarik perhatian dan mudah diterima oleh masyarakat, karena tidak terlalu mengejutkan dan memaksakan. ${ }^{35}$ Tuntunan agama Islam sendiri dijelaskan bahwa tidak boleh memaksa, dengan landasan ayat al-Qur`an لاكراه في الدين (tidak ada paksaan dalam agama).

Kemudian, dengan fakta sejarah tersebut dapat disaksikan bahwa agama Islam dapat dengan mudah dipeluk dan dianut oleh seluruh masyarakat Indonesia. Bagi mereka yang mempunyai pengetahuan keagamaan yang memadai akan menjadi Islam santri yang taat, sangat kontras dengan masyarakat yang kurang memperoleh pengetahuan keagamaan disebut dengan Islam abangan, yang kukuh memegang tradisi yang ada, ${ }^{36}$ yang mulai dikenalkan Islam dengan penyisipan ajarannya pada ritual tradisinya.

Konsep akulturasi yang digagas para pendahulu dijaga dan dipelihara dari generasi ke generasi, termasuk masyarakat Desa Jurung, sebagai upaya dalam menyiarkan agama Islam di Desa Jurug. Proses Islamisasi yang berlangsung di Desa Jurug martabat pada dua budaya yang berkembang dan meningkat kepada taraf yang lebih tinggi. Proses perubahan budaya tersebut dipindahkan dari suatu lingkungan budaya etnik tertentu kelingkungan budaya etnik yang lain. Disini terjadi pada tradisi tujuh bulanan (mitoni) yang bersumber dari majelis sima'an al-Qur’an Desa Jurug dengan pembacaan Surat Yūsuf dan Maryam.

Terjadinya proses akulturasi tersebut dapat dilihat dengan diterimanya kebudayaan luar, yaitu pembacaan Surat al-Qur`an yang dipadukan dengan kebudayaan mitoni, tanpa menghilangkan kepribadian kebudayaan asal. Dengan konsep akulturasi ini, terlihat bagaimana al-Qur`an mulai masuk dalam kehidupan sehari-hari masyarakat Desa Jurug terutama pada jamaah sima'an al-Qur'an. Sehingga digunakan dalam pelaksanaan tradisi tujuh bulanan (mitoni) dengan dibacakan Surat Yūsuf dan Maryam di dalam pelaksanaannya.

Singkatnya, akulturasi Islam dengan budaya lokal adalah suatu hal yang tidak dapat dipungkiri atau di hindari. Hal ini akan menjadikan Islam sebagai agama rahmatan li al'ālamīn dan șahịh likulli zamān wa makān. Ajaran agama Islam akan menjadi filter yang dapat menyaring adat atau budaya masyarakat, selama tidak bertentangan dengan ajaran agama, terutama nilai-nilai ketuhanan yang bebas dari persekutuan. Maka, hal ini dapat

\footnotetext{
${ }^{35}$ Wiji Saksono, Mengislamkan Tanah Jawa, Telaah atas Metode Da'wah Walisongo (Bandung: Mizan, 2009), hlm. 150.

${ }^{36}$ Clifford Geertz, Abangan, Santri, Priyayi Dalam Masyarakat Jawa (Jakarta: Pustaka Jawa, 1989), hlm. 17.
}

\section{AL-ITQAN, Volume 4, No. 2, 2018}


Islamisasi Budaya dalam Tradisi Tujuh Bulanan .....

Laili Choirul Ummah

Doi: doi.org/10.47454/itqan.v4i2.686

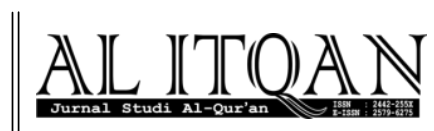

ditolerir, bahkan dapat dikembangkan sebagai khazanah budaya Islam dalam kehidupan masyarakat.

\section{Latar Belakang Sosial Budaya Masyarakat}

Pengertian budaya jika dikaitkan dengan manusia dapat dipahami bahwa manusia mempunyai dua segi atau sisi kehidupan, yaitu sisi material dan spiritual. Sisi material mengandung karya, yaitu kemampuan manusia untuk menghasilkan benda-benda atau yang lainnya berwujud materi. Sisi spiritual manusia mengandung cipta yang menghasilkan ilmu pengetahuan, karsa yang menghasilkan kaidah, kepercayaan, kususilaan, kesopanan hukum, serta rasa yang menghasilkan keindahan. Manusia berusaha mendapatkan ilmu pengetahuan melalui logika, menyerasikan perilaku terhadap kaidah melalui etika, dan mendapatkan keindahan melalui estetika. ${ }^{37}$

Budaya juga mencakup dua dimensi, yaitu fisik dan non fisik. Seperti bahasa, politik, agama, dan lain sebagainya. Dimensi budaya itulah yang akan mempengaruhi pola hidup sebuah kelompok. Menurut Muhammad Qasim Mathar, bahwa beragam pendapat dari sejumlah pakar yang mengemukakan bahwa seluruh bentuk tatanan hidup dalam masyarakat ditentukan oleh kebudayaan yang dimiliki oleh masyarakat itu sendiri. Kebudayaan digambarkan seperti produk turun temurun antar generasi yang merangkum unsur dan norma masyarakat itu sendiri. Adayang menjelaskan bahwa budaya merupakan perilaku kelompok yang teralokasi atau biasa disebut dengan budaya lokal. ${ }^{38}$

Budaya lokal memang tidak dapat dibatasi oleh sebagian dimensi budaya saja. Namun, budaya lokal tentu dibatasi oleh garis wilayah yang dihuni oleh setiap kelompok dalam masyarakat. Budaya Sumatera tentu berbeda dengan budaya Jawa, walaupun mungkin akan ditemukan beberapa perilaku yang sama dalam beberapa kelompok masyarakatnya. Hal tersebut disebabkan oleh ketidak-sengajaan maupun hasil dari perkawinan lintas budaya. Kemudian, budaya lokal inilah yang akan menciptakan pandangan kelompok yang berbentuk gagasan yang kemudian diwujudkan dengan berbagai produk budaya, baik yang berbentuk fisik ataupun non fisik.

Perpaduan dua budaya yang sehingga oleh karenanya akan menghasilkan budaya khas dan bercitra lokal sangat mungkin terwujud dalam suatu masyarakat. Sebab dalam setiap

\footnotetext{
${ }^{37}$ Hamzah Junaid, “Kajian Kritis Akulturasi Islam dengan Budaya Lokal”, Jurnal Diskursus Islam, vol. 1 no. 1(2013), hlm. 58.

${ }^{38}$ Muhammad Qasim Mathar, Fajar: Kolom Opini, 21 Agustus 2010, hlm. 4.
} 
pertemuan antara dua budaya, manusia akan membentuk, memanfaatkan, dan mengubah halhal yang paling sesuai dengan kebutuhannya. Dengan tolak ukur inilah dalam kerangka kebudayaan khususnya dalam proses akulturasi lahir dengan istilah kearifan lokal. Kearifan lokal terbentuk sebagai keunggulan budaya masyarakat setempat maupun kondisi geografis tertentu. Kearifan lokal merupakan produk budaya masa lampau yang patut dan perlu dijadikan pegangan secara terus menerus.

Berdasarkan data penelitian lapangan, didapatkan informasi bahwasannya di Desa Jurug masih mempertahankan adat istiadat Jawa, yang mana budaya tersebut juga telah mengalami akulturasi dengan budaya Islam. Hal tersebut dapat dibuktikan dalam tradisitradisi yang hingga kini masih dilaksanakan, seperti dalam siklus kehidupan yang berupa; kelahiran, kematian, pernikahan, hingga dalam gotong royong.

Dalam tradisi kelahiran, ada beberapa rangkaian acara untuk menyambut kelahiran bayi,dari sebelum hingga setelah jabang bayi lahir. di antaranya adalah mitoni yang diadakan ketika bayi berumur tujuh bulan didalam kandungan. Hal ini, akan menjadi objek kajian utama penulis dalam penelitian.

Adapun kegiatan yang dilakukan oleh masyarakat Desa Jurug yang berkaitandengan hal keagamaan yang bersifat kondisional meliputi; slametan dalam rangka mitoni, kelahiran, kematian, penempatan rumah baru, dan lain sebagainya.

Akar tradisi mitoni yang berada di Desa Jurug ini bermula dari ajaran Kiai Khoirun yang mengamalkan ilmunya yang didapat dari Pondok Pesantren Bangil, Pasuruan, Jawa Timur kepada masyarakat Desa Jurug, khususnya pada jamaah sima'an al-Qur`an yangdipimpin oleh istrinya, yaitu Ibu Nyai Siti Mukarromah. Menurut kiai Khoirun bahwaduluketika nyantri di pondok, ia pernah diajak oleh Kiai-nya untuk menghadiri undangan tujuh bulanan dengan membacakan Surat Yūsuf dan Maryam. Maka, dengan pengetahuan dan praktik keagamaan yang didapatkan dari pondok tersebut, beliau mencoba mengamalkannya kepada masyarakat Desa Jurug dan mendapatkan tanggapanyang baik. Berikut adalah hasilwawancarayangdilakukanpenulis: ${ }^{39}$

"Jika ada orang yang hamil, ketika dulu saya masih mondok, bahasa Bangilnya tingkeban, kalau disini disebut mitoni dibacakan Surat Yūsuf dan Maryam, itu bertujuan tafa'ulan, ngalap ketularan. Semoga anak yang dikandung jikalau lahir laki-laki, akan seperti Nabi Yūsuf, didalam parasnya maupun tingkah

\footnotetext{
${ }^{39}$ Wawancara dengan Khoirun,21 Desember 2018.
}

\section{AL-ITQAN, Volume 4, No. 2, 2018}



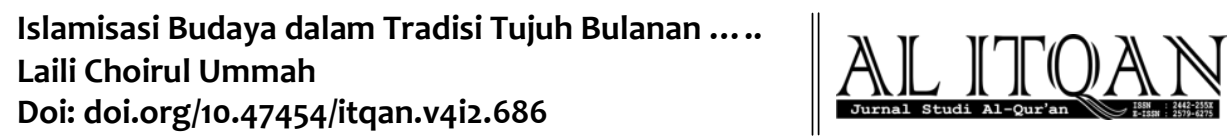

lakunya. Jikayang dikandung tersebut lahir perempuan, akan seperti Siti Maryam, karena Siti Maryam adalah wanita yang paling cantik sedunia,cantik paras dan budi pekertinya. Karena Siti Maryam adalah salah satu wanita pilihan Allah, seperti yang tertera dalam Surat Ali'Imron ayat 42.

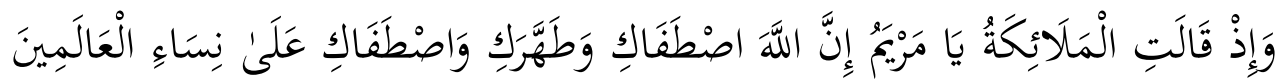

'Malaikat Jibril berkata kepada Siti Maryam,'Kamu adalah wanita yang dipilih oleh Allah, maka Allah mensucikanmu atas segala wanita didunia'. Berarti orang yang paling suci adalah Siti Maryam. Kemudian Nabi Yūsuf termasuk orang yang paling rupawan diseluruh dunia, selain Nabi Muhammad. Jadi, mulai dari Nabi Adam hingga hari kiamat, orang yang paling rupawan adalah Nabi Yūsuf. Seperti yang digambarkan dalam Surat Yūsuf ayat 31:

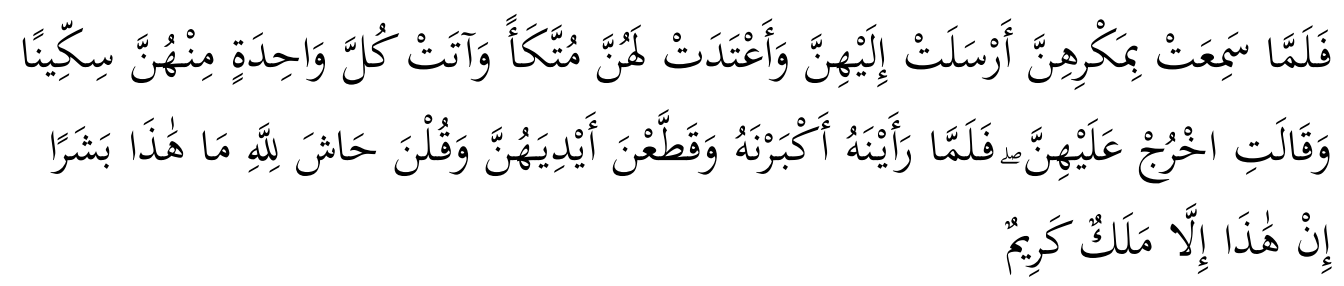

Maka, tujuan dibacakannya Surah Yūsuf dan Maryam tersebut adalah tafa'ulan, ngalap ketularan. Mengharap jika yang dilahirkan laki-laki seperti Nabi Yūsuf, dan jika yang dilahirkan adalah perempuan seperti Siti Maryam.”

Dari pemaparan Khoirun tersebut dapat diambil kesimpulan, bahwasannya munculnya pembacaan Surat Yūsuf dan Maryam berawal dari pemahaman atas apa yang dilakukan oleh Kiai-nya dalam mengamalkan Surah tertentu dalam al-Qur`an di dalam kehidupan sehari-hari. Kemudian, diterapkan dalam masyarakatnya sendirisehingga diterima dan diamalkan pula oleh masyarakat tersebut. Hingga akhirnya, memunculkan budaya baru,yaitu budaya Islam.

Living Qur`an yang dipraktekkan oleh umat Islam tidak melalui pendekatan teks atau bahasa al-Qur`an. Dalam hal ini disebabkan oleh karena masyarakat Desa Jurug, khususnya jamah sima'an al-Qur`an tidak mempunyai otoritas keagamaan dan tidak memiliki kemampuan dalam memahami bahasa al-Qur`an, sehingga mereka tidak pernah melakukan pendekatan terhadap bahasa maupun teks al-Qur`an. Jamaah sima'an al-Qur`an hanya mencoba secara langsung untuk berinteraksi, memperlakukan, dan menerapkan al-Qur`an dalam kehidupan sehari-hari mereka secara praktis.

Interaksi terhadap al-Qur`an semacam ini sudah menjadi budaya atau lebih tepatnya telah mendarah daging di dalam kalangan masyarakat Desa Jurug. Kemudian, pada akhirnya menghasilkan pola perilaku tertentu. Pola perilaku ini didasarkan pada asumsi-asumsi masyarakat terhadap objek yang dihadapi, yakni al-Qur`an. Asumsi-asumsi inilah yang disebut dengan pola berpikir, dengan meyakini bahwa al-Qur`an memiliki sumber 
keberkahan, kebaikan, dan keselamatan. Bagi masyarakat atau jamaah sima'an al-Qur'an Desa Jurug, cara interaksi ini lebih bermanfaat, dinamis, dan sangat mempengaruhi sisi psikologis dan spiritual mereka.

\section{Motivasi dan Keyakinan yang Mempengaruhi Pembacaan Surat Yūsuf dan Maryam dalam Tradisi Mitoni}

Akulturasi budaya pada umumnya terjadi sejak Islam masuk di Indonesia, khususnya di Pulau Jawa. Dengan demikian, akulturasi budaya akan menghasilkan budaya baru yang hadir dalam sebuah komunitas masyarakat. Begitu juga yang terjadi dalam masyarakat Desa Jurug khususnya pada jamaah sima'an al-Qur’an, pembacaan surahYūsuf dan Maryam dalam tradisi tujuh bulanan (mitoni) ini terjadi akibat adanya akulturasi budaya Islam dan Jawa. Tentu saja dalam akulturasi tersebut terjadi karena adanya sebab-sebab yang menjadi faktor adanya suatu budaya baru.

Dengan begitu, jika dikaitkan dengan pembacaan surah Yūsuf dan Maryam dalam tradisi mitoni ini, tentu saja banyak masyarakat yang mengatakan bahwa dengan dilaksanakannya pembacaan surah-surah tersebut akan mendatangkan berkah dan manfaat tersendiri. Hal ini mengindikasikan bahwa masyarakat Desa Jurug, khususnya pada jamaah sima'an al-Qur’an menggunakan kitab suci; al-Qur`an sebagai aspek non-kognitif. Penggunaan non-kognitif, yaitu penggunaan yang tidak memiliki hubungan dengan pengembangan pengetahuan. ${ }^{40}$ Selain itu, penggunaan non-kognitif ini ditekankan pada aspek spiritual, yang mana kitab suci dipercaya mendatangkan keberkahan dan menjauhkan dari kejahatan.

Khoirun memberikan sedikit penjelasan tentang makna yang terkandung dalam surah Yūsuf dan Maryam, namun tidak mendalam, yang menurut penulis itu bukanlah penjelasan melainkan sebuah doa, ia menyampaikan: ${ }^{41}$

"Kanthi waosan Surat Yūsuflan Maryam puniko,mugi-mugi diparingi keselametan ibu Sri Widyastuti lan si jabang bayi, dipunparingi sehat dumugi babaran. Mugi tansah dipunparingi putra ingkang sholeh lan bagus kados Nabi Yūsuf utawi sholihah lan ayu kados Siti Maryam".

"Dengan bacaan Surat Yūsuf dan Maryam tersebut, semoga diberi keselamatan untuk ibu Sri Widyastuti dan bayinya, diberi kesehatan hingga melahirkan.

\footnotetext{
${ }^{40}$ Robert E.Van Vorst, Anthology of World Scriptures, hlm. 10.

${ }^{41}$ Penelitian terlibat pada tanggal 12 Oktober 2018.
} 

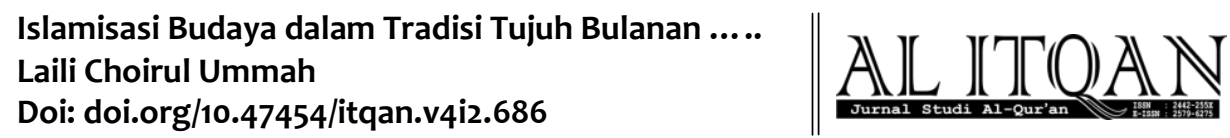

Semoga diberi putra yang saleh dan rupawan seperti Nabi Yūsuf atau saleha dan cantik seperti Siti Maryam.”

Khoirun tidak menjelaskan secara rinci tentang maknayang terkandung dalam kedua Surat tersebut, melainkan hanya sebuah intiyang diisyaratkan sebagai sebuah doa, permintaan agar anak yang dikandung dapat meniru akhlak dan paras Nabi Yūsuf dan Siti Maryam. Menurut penuturan ibu Suyati, jikapun pembacaan Surat Yūsuf dan Maryam tidak dilakukan juga tidak akan berpengaruh terhadap bayi yang dikandung, maupun orang-orang yang bersangkutan didalamnya. ${ }^{42}$ Namun, sugesti yang terjadi pada jamaah sima'an al-Qur`an Desa Jurug terhadap pembacaan Surat Yūsuf dan Maryam dalam tradisi mitoni ini begitu kuat dan berpengaruh dalam kehidupan sehari-hari mereka, sehingga masyarakat merasa harus melaksanakan pembacaan Surat tersebut dalam pelaksanaan tradisi tujuh bulanan(mitoni).

Jika dianalogikan dengan teori Farid Esack untuk menanggapi fenomena ini, pemahaman masyarakat tersebut yang tidak terlepas dari sugesti pembacaan Surat Yūsuf dan Maryam sebagai doa mengharap keberkahan. Dengan begitu, dalam keadaan semacam ini masuk dalam kategori the uncritical lover, kategori ini memposisikan al-Qur`an pada sesuatu yang tinggi, maka karena tingginya al-Qur`an tersebut, ia (kekasih) tidak dapat menjangkau makna terdalam yang sangat berharga darial-Qur`an. ${ }^{43}$ Dalam kategori ini, al-Qur`an menjadi sebuah wujud yang bernilai dengan sendirinya dan memberikan pengaruh kepada jamaah sima'an al-Qur’an dalam kehidupan sehari-hari.

Dengan begitu, maka akan terlihat bahwa masyarakat Desa Jurug, khususnya pada jamaah sima'an al-Qur`an,meyakini adanya al-Qur`an dapat memberikan suatu keberkahan dan kebaikan bagi si calon ibu dan bayi yang dikandungnya, jika telah dibacakan Surat Yūsuf dan Maryam. Meskipun, masyarakat pada umumnya tidak mengetahui bagaimana keberkahan tersebut dapat terjadi karena pembacaan Surat Yūsuf dan Maryam. Disini masyarakat hanya meyakini bahwa al-Qur`an adalah sesuatu yang suci, yang tidak perlu lagi dipertanyakan apalagi dikritisi kebenarannya.

Dalam sejarah tradisi mitoni di Desa Jurung, penyisipan pembacaan Surat Yūsuf dan Maryam pada prosesi tujuh bulanan (mitoni), untuk pertamakalinya dibawakanoleh Ibu Nyai Siti Mukarromah. Menurutnya, dengan adanya pembacaan surah al-Qur`an masyarakat akan lebih mudah mengenal ajaran Islam tanpa menyisihkan tradisi yang berkembang. Hal tersebut

\footnotetext{
${ }^{42}$ Wawancara denganSuyati,9 Oktober 2018.

${ }^{43}$ Faridesack, The Qur`an: A Short Introduction, hlm. 2.
} 
dimaksudkan agar tidak menimbulkan kontradiksi yang berlebihan dalam masyarakat, antara budaya Jawa dengan ajaran Islam. Selain itu masyarakat menganggap apa yang dibawa oleh bapak dan ibu nyai adalah suatu hal yang baik dan bermanfaat. ${ }^{44}$

Siti Mukarromah memanfaatkan tradisi tujuh bulanan (mitoni) dengan pembacaan surah Yūsuf dan Maryam sebagai media menyiarkan ajaran agama Islam di Desa Jurug. Namun, dalam proses kompromi kebudayaan tersebut juga menimbulkan resiko, dengan tidak menerimanya semua kalangan atas pembacaan surah-surah al-Qur`an dalam ritual tradisi, menafsirkannya sebagai hal yang telah menyimpang dengan ajaran Islam murni yang mewajibkan semua tindakan harus berdasarkan al-Qur`an dan Sunnah seperti beberapa kelompok keagamaan, Muhammadiyah, Majlis Tafsir Al-Qur`an.

Hal demikian tidak menyurutkan siar Islam yang dibawa oleh ibu nyai Siti Mukarromah, karena mayoritas jamaah telah menerima hal tersebut dengan baik dan terbuka. Kemudian hingga akhirnya, berbagai macam pemahaman tersebut dapat disimpulkan bahwa masyarakat, khususnya jamaah sima'an al-Qur`an telah menerima budaya Islam dalam budaya lokal secara bersamaan yaitu dengan memasukkan pembacaan Surat Yūsuf dan Maryam dalam tradisi tujuh bulanan (mitoni).

\section{E. Kesimpulan}

Masyarakat Desa Jurug, khususnya pada jamaah sima'an al-Qur`an memiliki adat kebiasaannya sendiri untuk memperingati tradisi tujuh bulanan (mitoni), yaitu dengan membaca Surat Yūsuf dan Maryam (living Qur`an) dalam pelaksanakannya.

Pembacaan Surat Yūsuf dan Maryam oleh masyarakat Desa Jurug, khususnya pada majelis sima'an al-Qur`an dianggap sebagai sesuatu yang baik dan memuat beberapa manfaat. Ajaran tersebut dibawa diperkenalkan oleh Bapak Khoirun dan ibu Nyai Siti Mukarromah sebagai tokoh agama di Desa Jurug.

Al-Qur`an mampu masuk dalam suatu budaya Desa Jurug, yang mana al-Qur`an dibacakan dalam tradisi tujuh bulanan (mitoni). Dengan begitu, akulturasi budaya dalam msyarakat Desa Jurug dapat hidup dengan dinamis dan harmonis tanpa menghilangkan budaya utama pada tradisi Jawa.

\footnotetext{
${ }^{44}$ Wawancara dengan Suyati,9 Oktober2018.
} 

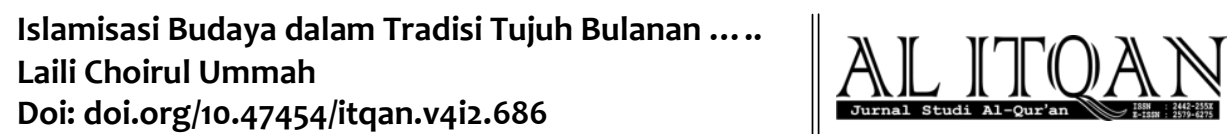

\section{DAFTARPUSTAKA}

Al-Dimashqīy, Syamsu al-Dīn Abū Ubaidillāh Muhammad bin Thālib. Nukhbat al-Dahr fi 'Ajāib al-Barr wa al-Baḥr. ttp: al-Akadimiyyah al-Embirāṭūriyyah, 1865.

Aminm Faizah \& Ananda, Rifki Abror. "Kedatangan dan Penyebarana Islam di Asia Tenggara: Tela'ah Teoritik Tentang Proses Islamisasi Nusantara", Analisis: Jurnal Studi Keislaman, vol. 18, no. 2(2018).

Chirzin, Muhammad. Mengungkap Pengalaman Muslim Berinteraksi dengan al-Qur`an. Yogyakarta: Teras, 2007.

D.Gill, Sam. Nonliterate Tradition and Holy Books: Toward a New Model. t.t: Denny and Taylor Holly Book, t,th.

Esack,Farid. The Qur`an: A Short Introduction. England: Oneworld Publication, 2002.

Hariwijaya, M. Islam Kejawen. Yogyakarta: Gelombang Pasang, 2006.

Isnawati. “Studi Living Qur’an Terhadap Amalan Ibu Hamil di Kecamatan Beruntung Baru Kabupaken Banjar” , Studia Insania, vol. 3, no.2 (2015).

Kholil, Ahmad. "Seblang dan Kenduri Masyarakat Desa Olehsari: Relasi Ideal Antara Islam dan Budaya Jawa di Banyuwangi”. el-Harakah, vol. 12, no. 2 (2012).

Koentjaraningrat. Kebudayaan Jawa. Jakarta: Balai Pustaka, 1994.

Kuntowijoyo. Dinamika Sejarah Umat Islam di Indonesia. Yogyakarta: Mata Bangsa, 2017.

Mathar, Muhammad Qasim Fajar. Kolom Opini, 21 Agustus 2010.

Moleong, LexyJ. Metode Penelitian Kualitatif. Bandung: Rosda Karya, 2004.

Monografi Desa Jurug Kecamatan Mojosongo Kabupaten Boyolali Tahun2018. Tanggal 29 Oktober 2018.

Mustaqim, Abdul. Metode Penelitian Living Qur`an Model Penelitian Kualitatif. Yogyakarta: Teras, 2007.

Nasution, Harun Ensiklopedi Islam Indonesial. Jakarta: Djambatan, 1992.

Negara, Ahmad Mansur Surya. Api Sejarah Jilid I. Bandung: Surya Dinasti: 2016.

Pusat Bahasa, Kamus Bahasa Indonesia. Jakarta: departeman Pendidikan Nasional, 2008. 


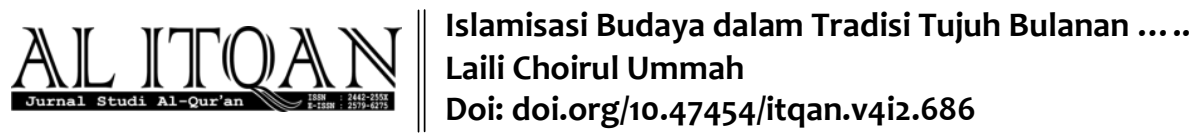

Saksono, Wiji. Mengislamkan Tanah Jawa, Telaah atas Metode Da'wah Walisongo. Bandung: Mizan, 2009.

Shihab, M. Quraish, dkk.Sejarah dan Ulum al-Qur`a.Jakarta: Pustaka Firdaus, 2001.

Sumbulah, Ummi. "Islam jawa dan Akulturasi Budaya: Karakteristik, Variasi, dan Ketaatan Ekspresif”. el Harakah, vol.14, no.1 (2012).

Vorst, Robert E. Van. Anthology of World Scriptures. USA: Thomson Corporation, 2008.

Woodward, Mark R. Islam Jawa; Kesalehan Normatif Versus Kebatinan, terj. Hairus Salim HS. Yogyakarta: LkiS, 2012.

\section{Wawancara}

Wawancara dengan Ibu Suyati, Mojosongo, Boyolali,9 Oktober,2018.

Wawancara dengan Bapak Kiai Khoirun, Mojosongo, Boyolali,21Desember,2018.

Wawancara dengan Ibu Suyati, Mojosongo, Boyolali, 13 Oktober, 2018. 